\title{
Article \\ Axial Load Behavior of Ultrahigh Strength Concrete-Filled Steel Tube Columns of Various Geometric and Reinforcement Configurations
}

\author{
Khandaker M. A. Hossain *(D), Katie Chu and Muhammed S. Anwar \\ Department of Civil Engineering, Ryerson University, 350 Victoria Street, Toronto, ON M5B 2K3, Canada; \\ katie.chu@ryerson.ca (K.C.); muhammedshabbeer@hotmail.com (M.S.A.) \\ * Correspondence: ahossain@ryerson.ca
}

Citation: Hossain, K.M.A.; Chu, K.; Anwar, M.S. Axial Load Behavior of Ultrahigh Strength Concrete-Filled Steel Tube Columns of Various Geometric and Reinforcement Configurations. Infrastructures 2021, 6 66. https://doi.org/10.3390/ infrastructures6050066

Received: 15 February 2021

Accepted: 27 April 2021

Published: 29 April 2021

Publisher's Note: MDPI stays neutral with regard to jurisdictional claims in published maps and institutional affiliations.

Copyright: (c) 2021 by the authors. Licensee MDPI, Basel, Switzerland. This article is an open access article distributed under the terms and conditions of the Creative Commons Attribution (CC BY) license (https:/ / creativecommons.org/licenses/by/ $4.0 /)$.

\begin{abstract}
This paper presents the behavior of concrete-filled steel tube (CFST) columns infilled with fiber-reinforced self-consolidating ultrahigh strength concrete (UHSC) subjected to axial concentric monotonic loading to failure. UHSC is expected to improve ease of fabrication, strength, and ductility of CFST columns. Seventeen columns having varying geometric properties such as tube wall thickness, cross-sectional shape (circular, rectangular, and square), and slenderness were constructed and tested by applying load through both steel tube and concrete core. Circular columns were further distinguished by the presence or absence of main and hoop steel reinforcing bars in the core concrete. Axial load-displacement response, axial/transverse strain development, and failure modes were recorded during the loading history to analyze the performance. Experimental confined concrete strength and axial strength of UHSC-filled CFST columns were compared with those obtained from three suggested analytical models and three code-based design procedures including Eurocode 4, Canadian CAN/CSA S16, and American AISC. Analytical models were found to over-predict the confined concrete strength and the axial strength of CFST columns. Canadian and American codes were found to be most applicable for predicting axial strength of UHSC-filled CFST columns while remaining conservative.
\end{abstract}

Keywords: composite columns; concrete-filled steel tubes; ultrahigh strength concrete; axial strength; confined concrete strength; design codes; analytical models

\section{Introduction}

Concrete-filled steel tube (CFST) columns provide structural benefits such as increasing strength and ductility compared with normal reinforced concrete columns [1,2], and such characteristics are expected to be applicable to structures in seismic areas [3,4]. Advantages in CFST columns come from confinement of concrete by the steel tube wall [5]. Slenderness often has an effect on column capacity in general, and this has been found to be true in CFST columns as well. Columns with increasing slenderness "length-to-diameter ratio (L/D) for circular section" or "length-to-depth (minimum dimension) ratio (L/d) for rectangular section", typically fail due to global buckling rather than steel yielding or local buckling. In the case of CFST columns, concrete confinement is not able to fully develop in slender columns [6]; thus, greater confinement is expected in shorter columns [7]. In addition, higher axial strength is expected to develop in CFST columns as compressive strength of core concrete increases due to confinement. Infill concrete plays a significant role in the structural behavior of filled tube columns. Circular columns are capable of achieving better confinement, and thus, higher strength compared with square columns [5,8]. The presence of steel bar reinforcements enables even higher strength and ductility in CFST columns [3,9]. Circular CFST columns have been studied by many authors in the past, and various analytical models and code provisions are based on CFST columns of circular cross-section. 
Recent advancement in technology has developed high performance concretes (HPCs) with properties superior to those of ordinary concrete such as improved strength, ductility and self-consolidating characteristics. Fiber-reinforced ultrahigh-strength concrete (UHSC) with very high strength is an emerging class of HPCs [10-12]. To address the increase in stiffness typically observed as concrete compressive strength increases, steel fibers have been introduced in UHSC. The presence of steel fibers has been found to improve ductility characteristics in UHSC [10]. The ability for UHSC to self-consolidate allows for concrete to be placed with ease, where additional compaction and vibration are unnecessary.

Over the years, research has been conducted on CFST columns with various types of HPC infill $[3,8,9]$. In recent years, experimental and numerical research studies have been conducted on the CFST columns with UHSC infill including fire performance [13-19]. The structural performance of axially loaded CFST circular columns was investigated through finite element simulation of the load-deformation response, UHSC brittleness characteristic, and confinement effect using a new stress-strain model of confined UHSC [13]. CFST columns with UHSC exhibited similar fire performance compared to those with normal or high-strength concrete with respect to thermal expansion, axial contraction, and failure modes [14]. Adding 0.1\% polypropylene fibers in UHSC was also found to be effective in preventing explosive spalling heated rapidly under the standard fire [13]. Concrete-filled double-tube columns were also investigated for potential application in multi-story and high-rise constructions [15]. Test results showed that UHSC-filled tubular columns achieved ultrahigh load-carrying capacities, but they could become brittle after the maximum load was attained. In addition, the ductility and strength of composite columns infilled with UHSC were improved by applying load only on the concrete core, adding steel fibers into the concrete core or increasing the steel contribution ratio. Comparison of test results indicates that the Eurocode 4 [20] approach underestimated the resistance by $14.6 \%$ if the confinement effect was not considered and by $3.5 \%$ if the confinement effect was considered for all the specimens involving UHSC [15]. Use of fiber-reinforced UHSC can add to the strength and ductility of CFST columns [14-19].

Despite previous research studies, more investigations are needed to study strength, deformation, and failure characteristics of circular, square, and rectangular UHSC-filled CFST columns with varying geometric parameters and presence or absence of longitudinal and hoop reinforcements in the core concrete. The confining effect of a steel tube on concrete core in presence or absence of hoop reinforcement in addition to longitudinal reinforcement needs to be investigated. There is a need to evaluate the performance of existing models for predicting the strength of confined concrete in UHSC-filled CFST columns of various cross-sectional shapes. Existing design codes have placed limits on the strength of steel and concrete due to limited test data and experience on the behavior of CFST columns with UHSC. The performance of existing code-based design procedures in predicting axial strength of UHSC infilled CFST columns also needs to be studied.

To address the above needs, a comprehensive research consisting of experimental and analytical investigations has been conducted on the axial load behavior of UHSC infilled CFST columns. This paper presents the results of these investigations. The influences of variables such as tube shape/dimension/thickness, slenderness ratio and presence or absence of longitudinal and hoop reinforcements on axial load-deformation responses, strain characteristics and failure modes are described. The performance of various codebased design equations such as European Eurocode 4 [20], Canadian CAN/CSA S16-09 [21], and American AISC [22] for strength prediction is evaluated. As a novel contribution of this study, analytical models for confined strength of UHSC and axial strength of CFST columns are derived based on existing models and their performance validated through comparison with test results. The findings of this research and the proposed analytical models will surely benefit engineers and researchers involving in the design and construction of UHSC infilled CFST columns. 


\section{Experimental Program}

\subsection{Column Sample Specifications}

Seventeen CFST columns were prepared using circular (c), square (s), and rectangular (r) steel tubes with UHSC infill developed at Ryerson University. Detailed designations with geometric dimensions of columns such as tube thickness ( $t)$, diameter (D), breadth (b)/depth (d: smaller dimensions) of the cross-section, length/height (L), breadth-tothickness ratio $(b / t)$, diameter-to-thickness ratio $(D / t)$, and slenderness $(\mathrm{L} / \mathrm{D}$ or $\mathrm{L} / \mathrm{d})$ are presented in Table 1.

Table 1. Geometric dimension and designations of CFST columns with test results.

\begin{tabular}{llllllllll}
\hline Column Desig. & $\mathbf{L}, \mathbf{m m}$ & $\mathbf{t}, \mathbf{m m}$ & $\mathbf{D}, \mathbf{m m}$ & $\mathbf{b}, \mathbf{m m}$ & $\mathbf{d}, \mathbf{m m}$ & $\mathbf{D} / \mathbf{t}$ or b/t & $\mathbf{L} / \mathbf{D}$ or $\mathbf{L} / \mathbf{d}$ & $\mathbf{P}_{\text {exp }}, \mathbf{k N}$ & Failure Mode \\
\hline UcI-3 & 342 & 4.8 & 114 & - & - & 24 & 3 & 1681 & Radial expansion \\
UcI-4 & 456 & 4.8 & 114 & - & - & 24 & 4 & 1610 & Shear \\
UcI-9 & 1026 & 4.8 & 114 & - & - & 24 & 9 & 1573 & Shear \\
UcII-3 & 342 & 4.8 & 114 & - & - & 24 & 3 & 1853 & Radial expansion \\
UcII-4 & 456 & 4.8 & 114 & - & - & 24 & 4 & 1849 & Shear \\
UcII-9 & 1026 & 4.8 & 114 & - & - & 24 & 9 & 1751 & Global buckling \\
Ur-6 & 306 & 3.2 & - & 102 & 51 & 32 & 6 & 809 & Shear \\
Ur-12 & 612 & 3.2 & - & 102 & 51 & 32 & 12 & 987 & Shear \\
Ur-20 & 1020 & 3.2 & - & 102 & 51 & 32 & 20 & 754 & Global buckling \\
Us4-3 & 306 & 3.2 & - & 102 & 102 & 32 & 3 & 1535 & Radial expansion \\
Us4-6 & 612 & 3.2 & - & 102 & 102 & 32 & 6 & 1397 & Local buckling \\
Us4-10 & 1020 & 3.2 & - & 102 & 102 & 32 & 10 & 1446 & Local buckling \\
Us2-6 & 306 & 1.6 & - & 51 & 51 & 32 & 6 & 330 & Shear \\
Us2-9 & 459 & 1.6 & - & 51 & 51 & 32 & 9 & 376 & Shear \\
Us2-12 & 612 & 1.6 & - & 51 & 51 & 32 & 12 & 348 & Shear \\
Us2-16 & 816 & 1.6 & - & 51 & 51 & 32 & 16 & 366 & Global buckling \\
Us2-20 & 1020 & 1.6 & - & 51 & 51 & 32 & 20 & 326 & Global buckling \\
\hline
\end{tabular}

L: length or height; $t$ : tube wall thickness; D: tube outer diameter; b: breadth (larger dimension of rectangular section); d: depth (minimum dimension for rectangular section); $b / t$ : diameter-to-thickness or depth-to-thickness ratio; $\mathrm{L} / \mathrm{D}$ or $\mathrm{L} / \mathrm{d}$ : slenderness ratio; $\mathrm{P}_{\text {exp }}$ : experimental axial load capacity/strength; U: UHSC; c: circular; s: square; r: rectangular; I and II: with and without longitudinal and hoop reinforcement, respectively.

Columns were designated by infill material (U—ultrahigh-strength concrete), column cross-sectional shape (c, s, or r) and Series I or Series II (without or with longitudinal and tie/hoop reinforcements, respectively for circular columns only). For example, UcII-9 represents Series II UHSC circular column with a L/D of 9. All square and rectangular columns are Series I columns and "I" was not used in their designations. For example, Us2-9 represents Series I square columns with a L/d ratio of 9. Circular columns were made of $114 \mathrm{~mm}$ diameter steel tubes with a thickness of $4.8 \mathrm{~mm}$ (Figure $1 \mathrm{a}-\mathrm{c}$ ), square columns were made of tubes with $51 \times 51 \times 1.6 \mathrm{~mm}$ and $102 \times 102 \times 3.2 \mathrm{~mm}$ cross-sections, and rectangular columns were made of $102 \times 51 \times 3.2 \mathrm{~mm}$ tubes (Table 1 ).

The effect of variables such as cross-sectional area, tube shape, tube thickness, and slenderness (as measured by L/D or L/d ratio) on behavior of CFST columns infilled with self-consolidating fiber-reinforced UHSC was investigated. In addition, four longitudinal bars and hoop reinforcements were incorporated in several Series II circular CFST columns. Longitudinal bars were bent at the ends in the configuration as shown in Figure 1a-c, where hoop/tie spacing and reinforcement specifications are given for circular Series II columns of varying height. 


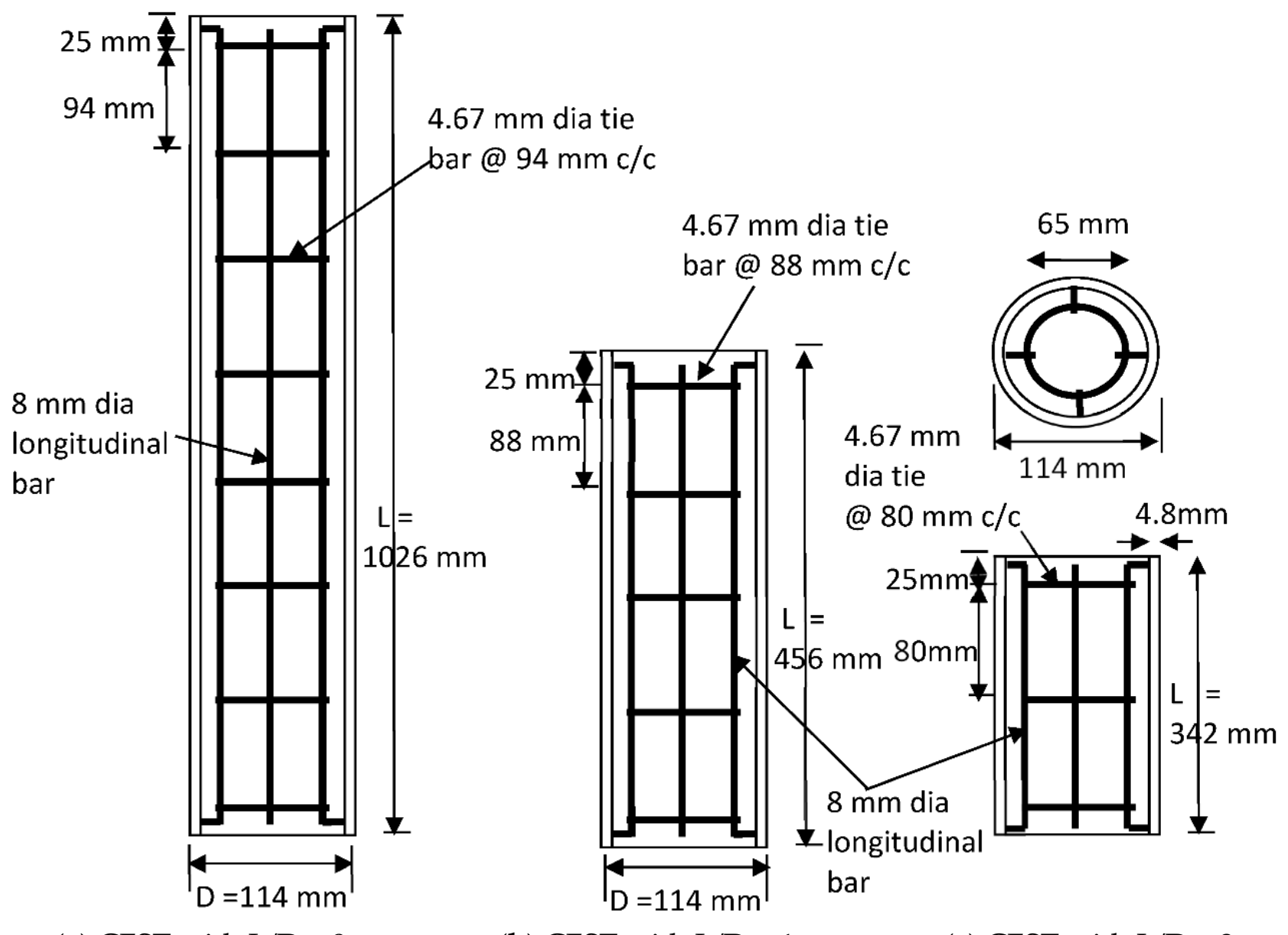

(a) CFST with $\mathrm{L} / \mathrm{D}=9$

(b) CFST with $\mathrm{L} / \mathrm{D}=4$

(c) CFST with $\mathrm{L} / \mathrm{D}=3$

Figure 1. Details of Series II circular CFST columns with longitudinal and hoop reinforcements.

\subsection{Specimen Casting, Curing, Instrumentation, and Testing}

UHSC mix developed at Ryerson University made of Type 10 (GU) cement as per Canadian Standard Association (CSA) specifications, silica sand, silica fume, superplasticizer (SP), and $13 \mathrm{~mm}$-long straight steel fibers with diameters of $0.2 \mathrm{~mm}$ were used. UHSC was mixed in a $150 \mathrm{~L}$ capacity shear mixer where water and superplasticizer were added to dry materials excluding steel fiber and mixed. Then steel fibers were added gradually on to the lubricated flowable mixture during further mixing for even distribution. After making, UHSC was poured directly into the steel tube without any manual compaction as the concrete was designed to consolidate under its own weight. Casting was done in a vertically upright position as shown in Figure 2a and UHSC was poured from the top of the specimen. During casting, control specimens in the form of $100 \mathrm{~mm} \times 200 \mathrm{~mm}$ cylinders and prisms were also made to determine UHSC compressive and flexural strengths, respectively at the age of testing. After casting, column and control specimens were covered for $24 \mathrm{~h}$ to prevent moisture loss and then air cured until testing at 28 days.

Figure 3 shows typical compressive stress-strain and flexural stress-displacement curves for UHSC. The mean 28-day cylinder compressive strength of UHSC (as derived from 15 specimens) was $130 \pm 3 \mathrm{MPa}$. The yield strength and modulus of elasticity of steel tubes and reinforcing bars were also determined from coupon tests. The yield strengths of longitudinal and hoop reinforcements were 635 and $662 \mathrm{MPa}$, respectively. The yield strength of circular, rectangular, square $(102 \times 102 \mathrm{~mm})$ and square $(51 \times 55 \mathrm{~mm})$ tubes were $333,372,351$, and $365 \mathrm{MPa}$, respectively while modulus of elasticity were 176, 236, 205, and $206 \mathrm{GPa}$, respectively. 
The test setup is shown in Figure $2 \mathrm{~b}$. Before testing at the age of 28 days, two strain gauges (g1 and g2) were installed on the sanded surface of steel tubes of circular and square/rectangular columns according to the configurations shown in Figure 2c in order to record lateral strain and axial strain, respectively, during testing. Linear voltage displacement transducers (LVDTs) were installed to measure lateral displacement of the columns (Figure 2b) while load and axial displacement were directly provided by the loading machine. The top and bottom surfaces of the columns were grinded flat in order to apply load evenly over the cross-section and to avoid undesired load eccentricity. In addition, in most of the columns, two axial strain gauges (g2) were installed on opposite faces of the steel tube. Equal axial strain development during initial stages of loading ensured concentric application of loading. The columns were loaded axially under static monotonic loading at a rate of $0.2 \mathrm{MPa} / \mathrm{s}$ under load control until failure. During loading history till failure, strains, load, and axial/lateral displacements were recorded through a computer-aided data acquisition system. In addition, buckling of steel tube and failure mode of column specimens were also observed.

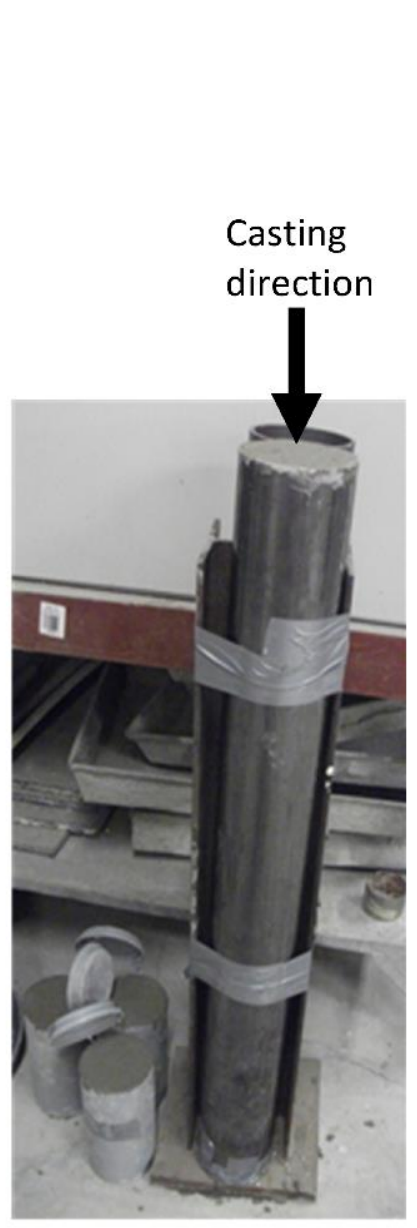

(a) Casting
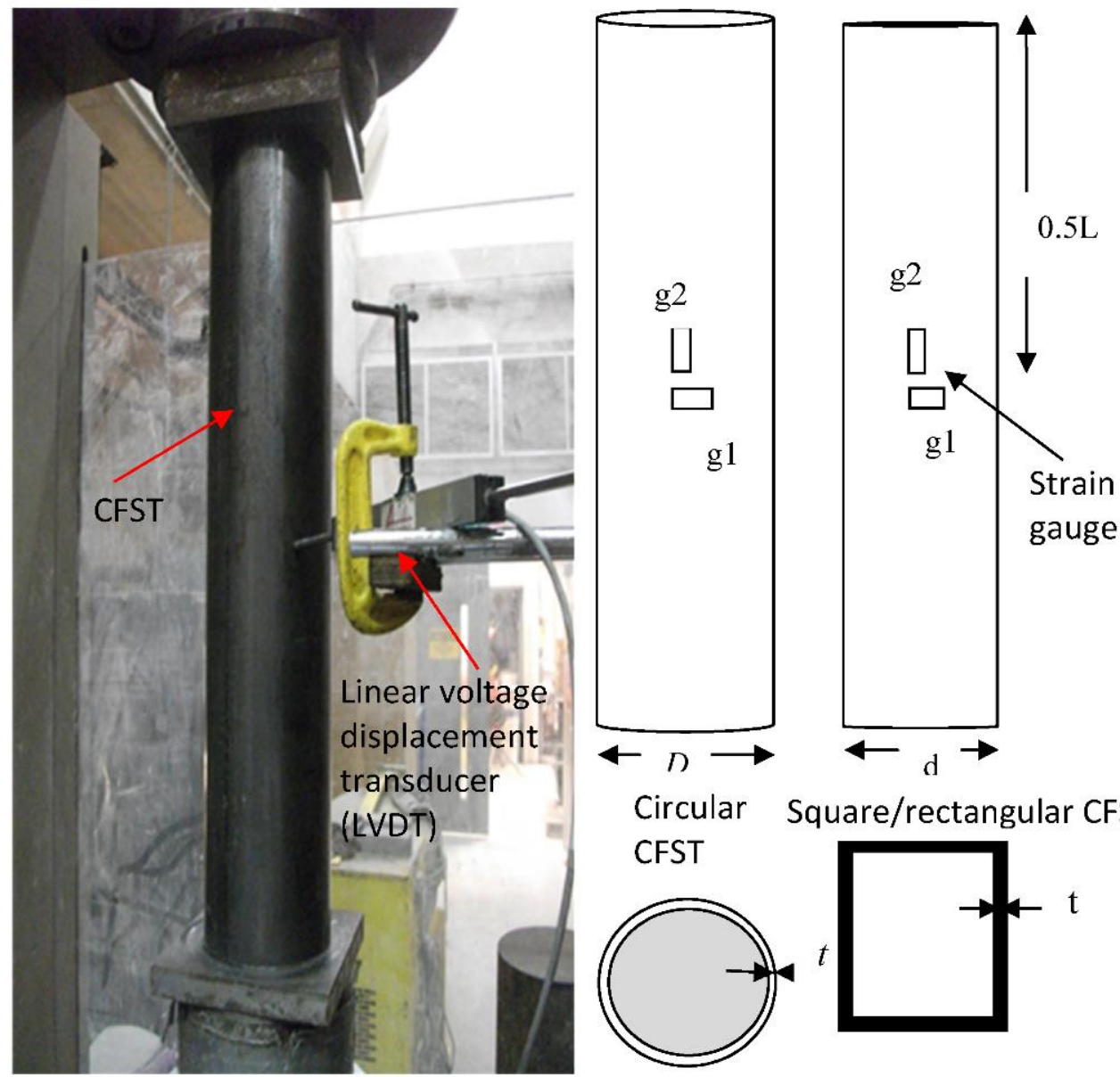

Circular

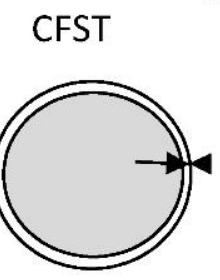

Square/rectangular CFST

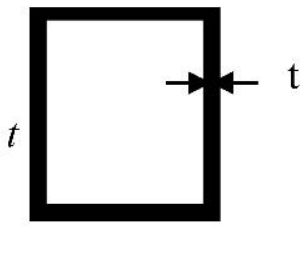

(c) Cross-section and instrumentation

Figure 2. Experimental setup, casting, and instrumentation of CFST columns. 


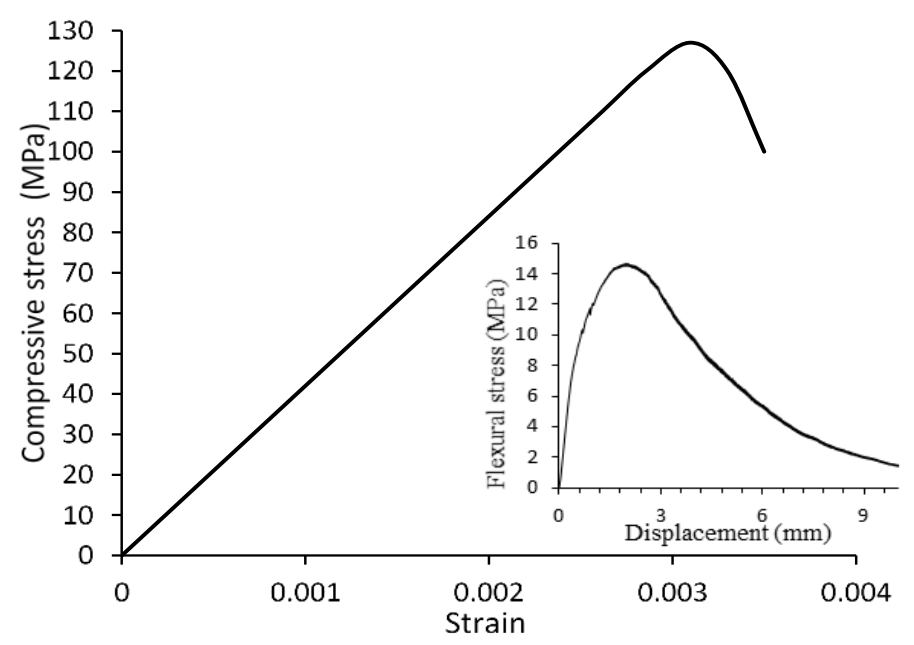

Figure 3. Typical compressive stress-strain and flexural stress-displacement responses of UHSC.

\section{Results and Discussion}

\subsection{Load-Displacement Responses and Failure Modes of CFST Columns}

Axial load-displacement responses of UHSC-filled CFST columns are shown in Figure 4a,b. All columns displayed similar behavior up to the first peak load. The rising and falling of axial load in the responses are attributed to the formation of multiple cycles of local buckling and their stabilization in formation of successive local buckles as confirmed from previous research studies [3]. The first peak load always governed the maximum capacity of most of the columns, especially with square and rectangular cross-sections. Square and rectangular UHSC-filled columns behaved similarly, as a large decrease in axial load often occurred after the first peak load. However, CFST columns of circular cross-section and lower slenderness gained greater load capacity after the first peak load or had no significant first peak load at all as observed in Series II columns (Figure 2a). Circular columns showed greater ductility (in terms of post first peak deformation) compared with square and rectangular CFST infilled with UHSC (Figure 4a,b). The addition of bar reinforcements in Series II columns improved strength and ductility even more as observed in other studies [3].

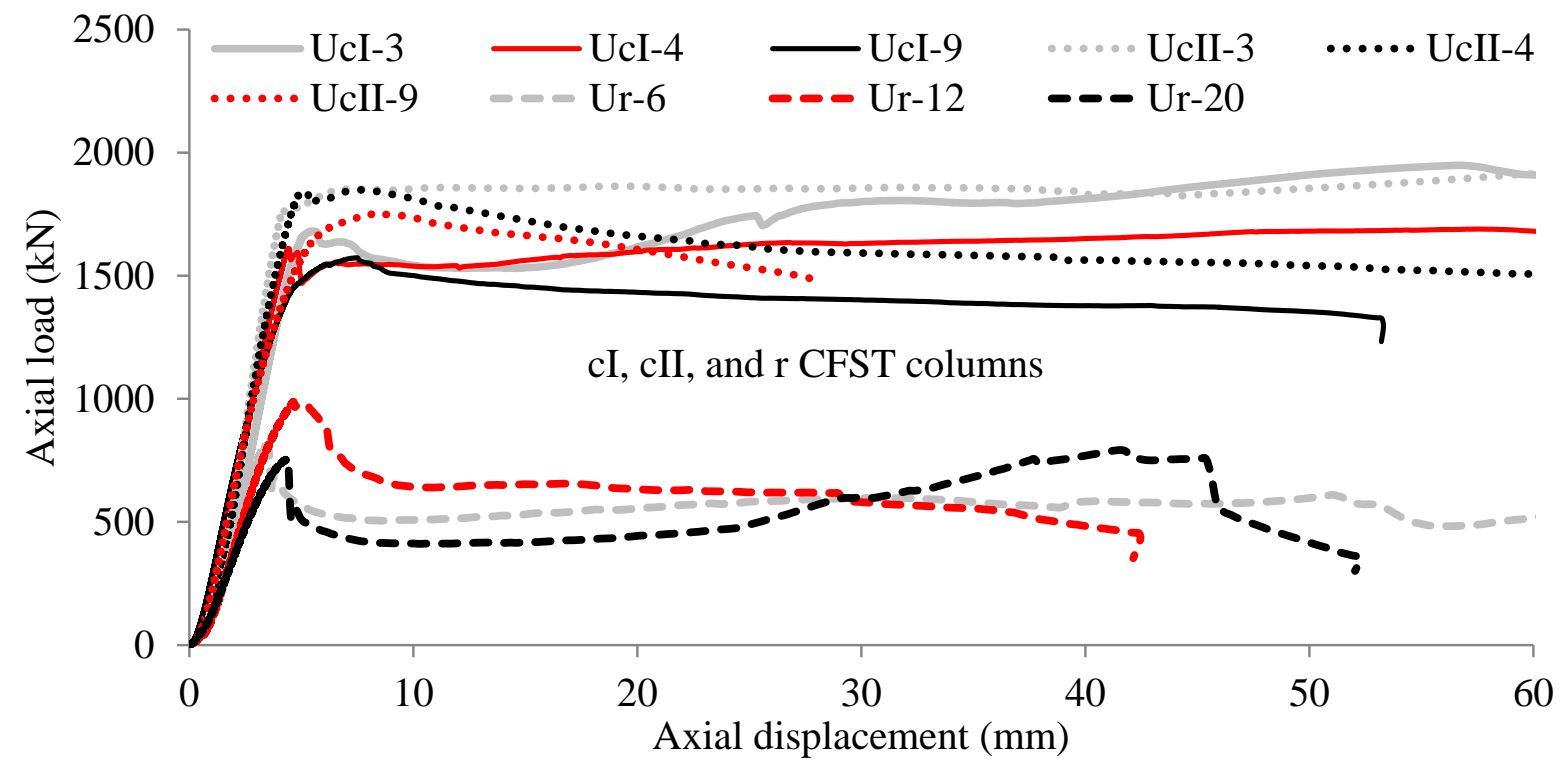

(a)

Figure 4. Cont. 


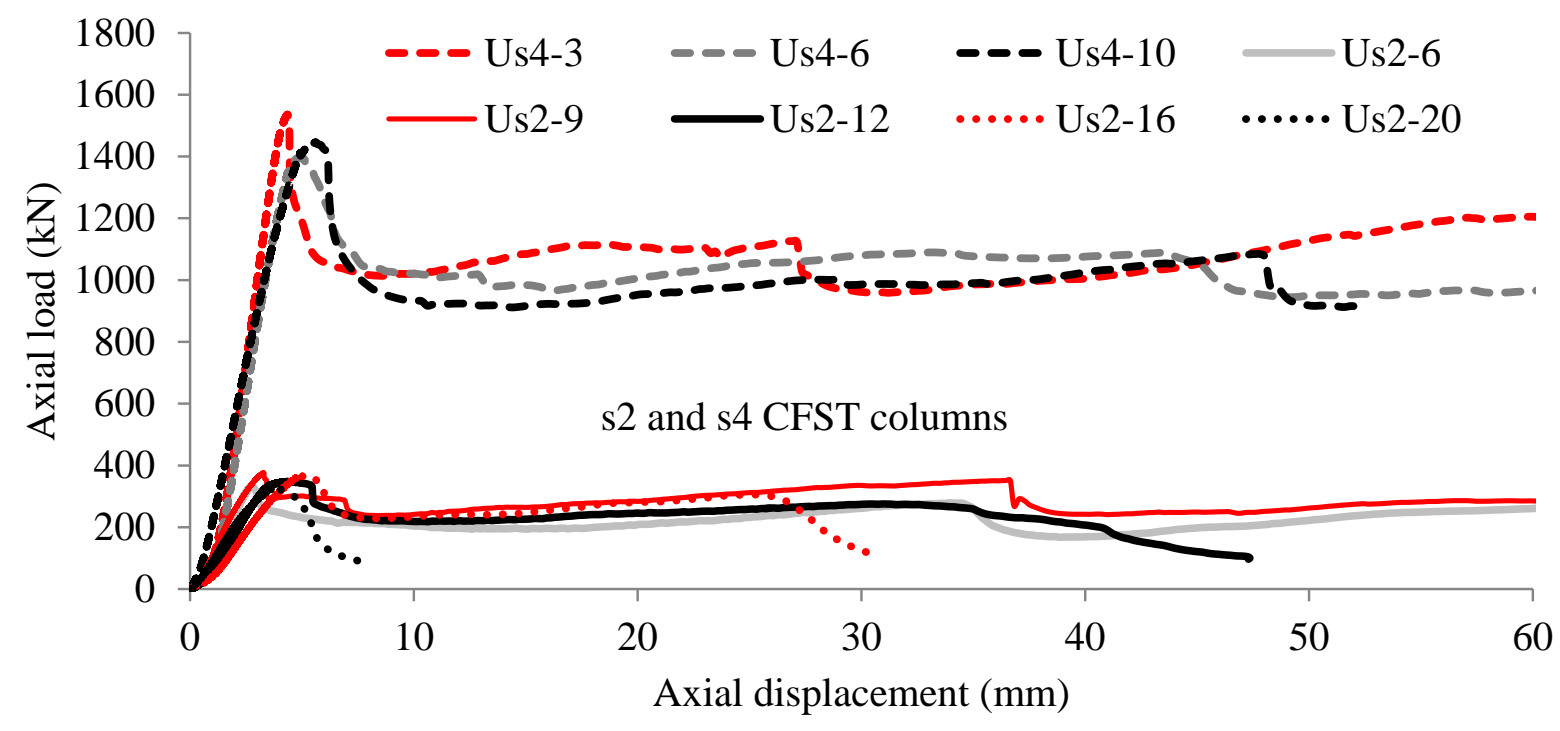

(b)

Figure 4. (a): Load-displacement responses of circular (CI and CII) and rectangular CFST columns. (b): Load-displacement responses of square CFST columns.

Figure 5 shows the failure modes of CFST columns. Table 1 summarizes failure modes and experimental axial capacity $\left(\mathrm{P}_{\mathrm{u}}\right)$ of columns. Columns with slenderness ratios of 20 and 16 failed by global buckling at mid-height, and those with L/D ratios of 12, 10, 9, 6, and 4 often failed by shear and local buckling (Figure 5 and Table 1). All columns with a L/D ratio of 3 failed due to concrete radially expanding at mid-height, resulting in tearing of the steel wall. In general, slender columns failed due to global buckling while short columns (low slenderness) exhibited failure due to local buckling and plastic yielding of regions between local buckling showing significant bulging and tearing of steel. Experimental ultimate axial strength capacities were larger for columns with larger cross-sectional areas.

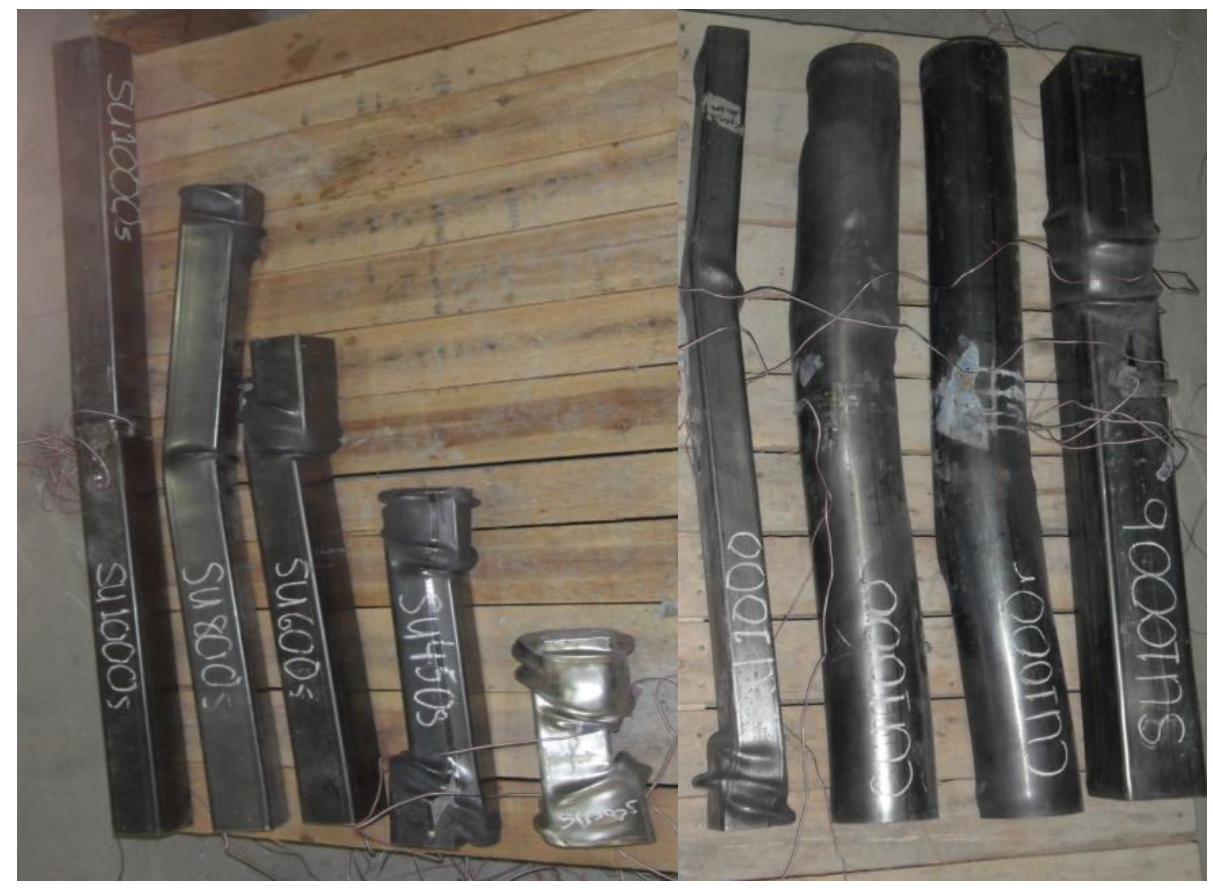

Figure 5. Failure modes of UHSC-filled CFST columns (from left: Us2-20, Us2-16, Us2-12, Us2-9, Us2-6, Ur-20, UcI-9, UcII-9, and Us4-10). 
Figure 6 presents the variation of axial load capacity of CFST columns with slenderness (L/D and L/d). Axial load capacity generally decreased with the increase in slenderness. The presence of longitudinal reinforcement with hoop/ties (Series II) increased the axial load capacity of circular columns compared to Series I columns. Circular columns (cI) showed higher axial load capacity compared to their rectangular (r) counterparts. For circular UcI columns, axial strength decreased from 1681 to $1573 \mathrm{kN}$ (6.4\% decrease) while the UcII columns' strength decreased from 1853 to $1751 \mathrm{kN}$ (5.6\% decrease) when the L/D ratio increased from 3 to 9 . Circular CII columns exhibited higher (10 to 15\%) strength than CI columns, as expected. Similar strength reduction was also observed for rectangular CI columns (Ur) (from 809 to $754 \mathrm{kN}$ - a 6.8\% decrease for L/d varying from 3 to 9) and for square (Us) columns (from 376 to $326 \mathrm{kN}$-a 13.3\% decrease for L/d from 9 to 20).

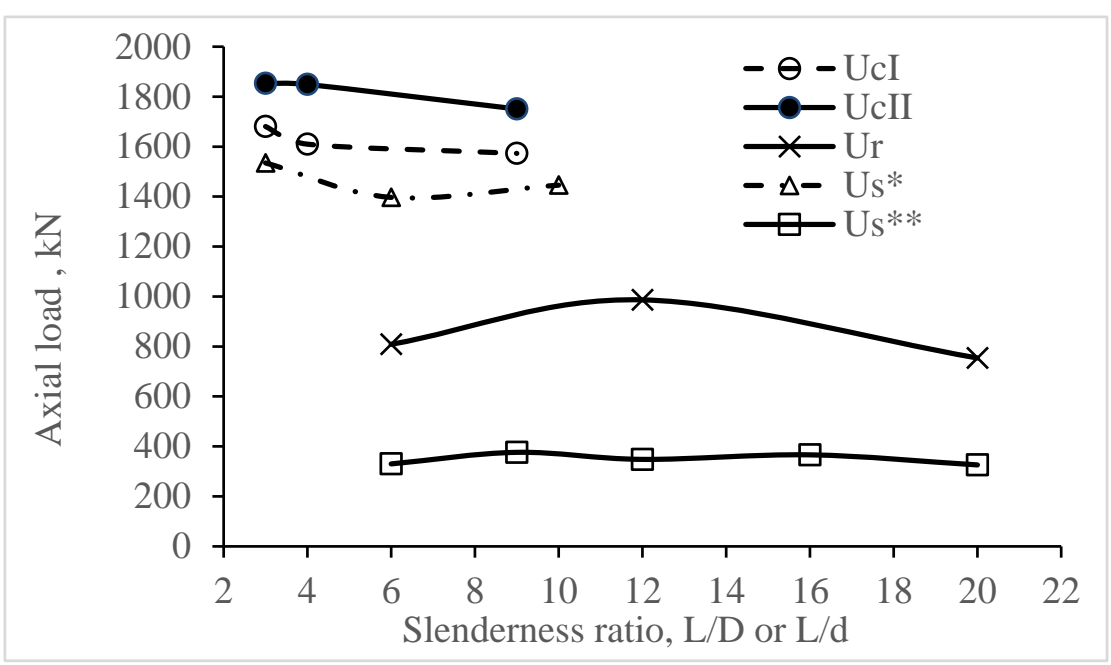

Figure 6. Axial load capacity of CFST columns and effect of slenderness.

Overall the axial strength of the columns depends on the combined effect of $D / t, L / D$ or L/d, shape of the steel tube, and failure modes as observed in past research studies [5]. The confinement effect provided by the steel tube is demonstrated by the enhanced ultimate load capacity of UHSC infilled CFST columns using UHSC. However, matching of UHSC with a particular steel tube is necessary to effectively improve the ultimate load capacity of CFST columns as confirmed from other research studies $[13,16]$.

\subsection{Analysis of Stress-Strain Behavior in CFST Columns}

\subsubsection{Biaxial Stress Development and Confinement in CFST Columns}

Under axial compression load, the concrete core of CFST columns begins to crack. After cracking, the concrete dilates creating lateral pressure on the steel tube. The concrete is under triaxial confinement from the presence of the steel tube, while the steel tube is under biaxial stress due to axial load and lateral hoop stresses developed from the concrete core pushing outwards on the tube wall. Therefore, biaxial yielding in steel can be modeled by the von-Mises failure criterion in Equation (1) $[9,23]$.

$$
f_{y s}^{2}=\sigma_{a}^{2}+\sigma_{h}^{2}-\sigma_{a} \sigma_{h}
$$

where $\sigma_{a}=\beta f_{y s}, \sigma_{h}=\alpha f_{y s}$.

The von-Mises yield stress $\left(f_{y s}\right)$ is constant and taken as the steel tube yield strength. Each $f_{y s}$ value corresponds to a different failure envelope. Axial stress and hoop stress denoted by $\sigma_{a}$ and $\sigma_{h}$ respectively can be obtained from experimental strain data. The various combinations of axial and transverse stresses contributing to biaxial yield stress forms the von-Mises stress path shown in Figure 7. 


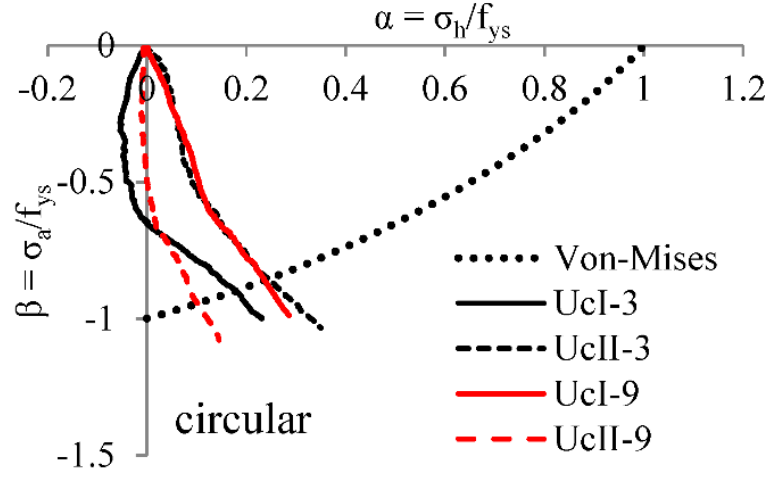

(a) Circular CFST

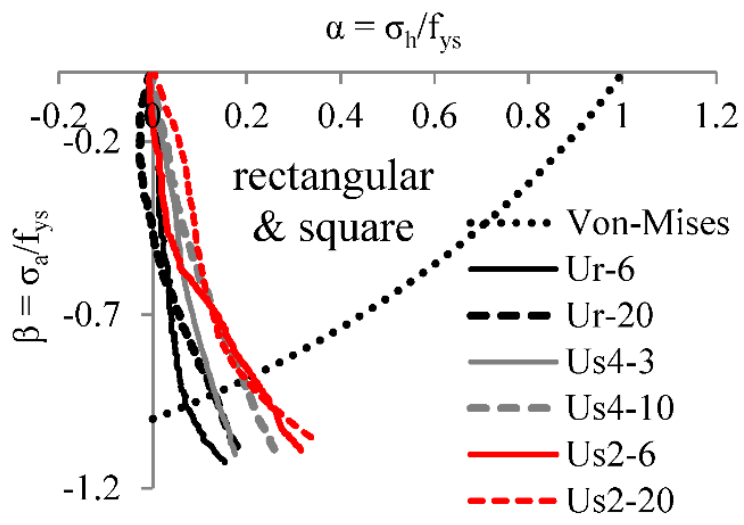

(b) Rectangular and square CFST

Figure 7. Development of biaxial stresses in UHSC CFST columns.

Development of biaxial stresses in UHSC CFST columns are compared in Figure 7a,b). The transverse stress factor and axial stress factor, $\alpha$ and $\beta$ in Equation (1), can be determined at the location where experimental stresses intersect the theoretical von-Mises failure criterion. Axial stress factor $(\beta)$ is found to be greater than transverse stress factor $(\alpha)$, as axial stresses develop in early stages of loading while transverse stresses develop after concrete begins to dilate and induce transverse stresses in the steel tube [24].

Figure $8 \mathrm{a}, \mathrm{b}$ shows typical experimental axial and transverse (hoop) strain development in UHSC CFST columns, illustrating significantly greater axial strain development while transverse strain often did not reach theoretical steel yield strain for columns with high slenderness. Experimental stress factors $\alpha$ and $\beta$ are presented in Table 2 for UHSC-filled CFST columns.

Table 2. Stress factors.

\begin{tabular}{|c|c|c|c|c|c|c|}
\hline \multirow{2}{*}{$\begin{array}{c}\text { Column Type } \\
\text { UcI }\end{array}$} & \multicolumn{2}{|c|}{$L / D$ or $L / d$} & \multicolumn{2}{|c|}{$\alpha$} & \multicolumn{2}{|c|}{$\beta$} \\
\hline & 3 & 9 & 0.17 & 0.23 & 0.89 & 0.85 \\
\hline UcII & 3 & 9 & 0.24 & 0.10 & 0.84 & 0.93 \\
\hline Ur & 6 & 20 & 0.07 & 0.13 & 0.96 & 0.93 \\
\hline Us4 & 3 & 10 & 0.13 & 0.19 & 0.93 & 0.89 \\
\hline Us2 & 6 & 20 & 0.21 & 0.20 & 0.88 & 0.89 \\
\hline
\end{tabular}

Axial strain

Transverse/hoop strain

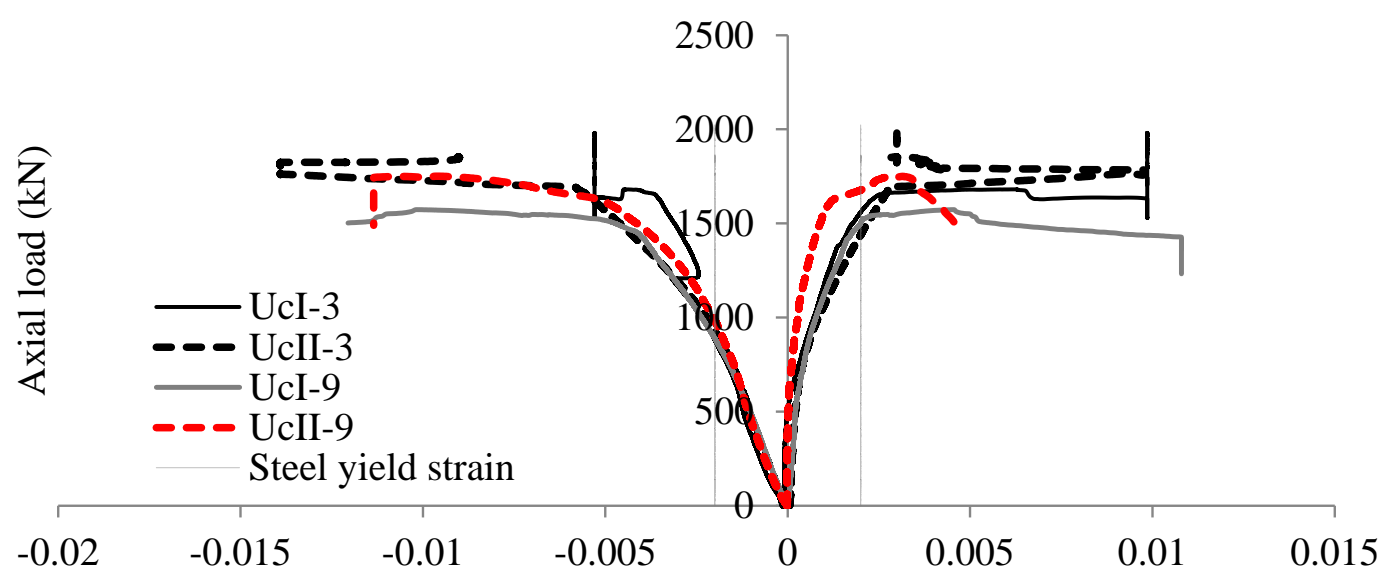

(a)

Figure 8. Cont. 


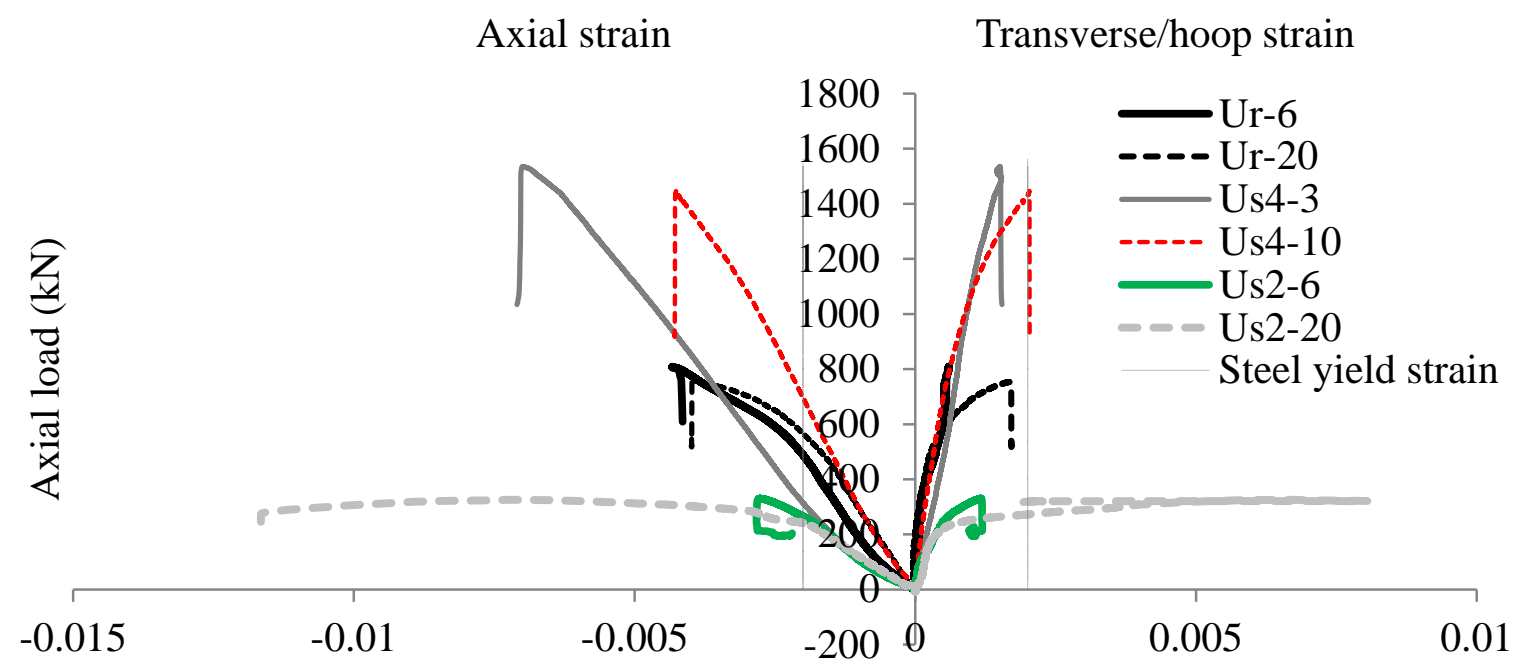

(b)

Figure 8. (a): Typical axial load-steel tube strain development in circular CFST columns. (b): Typical axial load-steel tube strain development in square/rectangular CFSTs.

Table 3 summarizes the ultimate axial load $\left(P_{u}\right)$, axial strain at ultimate axial load $\left(\varepsilon_{u}\right)$, load at biaxial yielding $\left(P_{y s}\right)$, and axial strain at biaxial yielding $\left(\varepsilon_{y s}\right)$ of tested CFST columns infilled with UHSC. The point of biaxial yielding where $P_{y s}$ and $\varepsilon_{y s}$ are determined is based on von-Mises failure criterion described previously in Equation (1). $\varepsilon_{y s} / \varepsilon_{u}$ ratios are found to be always greater than 1 as biaxial steel yielding always occurred before the axial capacity of the columns (Table 3 ). $P_{y s} / P_{u}$ ratios indicate that the axial strength of CFST columns occurred between 1.99 and 6.85 times the load at biaxial yielding indicating that steel yielding was not the final cause of failure of CFST columns (Table 3). In all columns, steel yielded both uniaxially and biaxially before the failure. Shorter columns (with lower slenderness) had generally higher $P_{u} / P_{y s}$ ratios compared to longer columns. Higher $P_{u} / P_{y s}$ ratios $(>1.0)$ show that the shorter columns had the ability to take relatively larger amount of additional load (even after the biaxial steel yielding) before failure which can be attributed to the higher ductility behavior of such columns.

Table 3. Biaxial steel yielding and associated ductility in UHSC CFST columns.

\begin{tabular}{ccccccc}
\hline Column & $\boldsymbol{P}_{\boldsymbol{u}}, \mathbf{k N}$ & $\boldsymbol{\varepsilon}_{\boldsymbol{u}}$ & $\boldsymbol{P}_{\boldsymbol{y} \boldsymbol{s}}, \mathbf{k N}$ & $\boldsymbol{\varepsilon}_{\boldsymbol{y s}}$ & $\boldsymbol{P}_{\boldsymbol{u}} / \boldsymbol{P}_{\boldsymbol{y s}}$ & $\varepsilon_{\boldsymbol{u}} / \boldsymbol{\varepsilon}_{\boldsymbol{y s}}$ \\
\hline UcI-3 & 1681 & -0.004486 & 761 & -0.001682 & 2.21 & 2.67 \\
UcI-9 & 1573 & -0.010181 & 750 & -0.001600 & 2.10 & 6.36 \\
UcII-3 & 1853 & -0.009041 & 778 & -0.001594 & 2.38 & 5.67 \\
UcII-9 & 1751 & -0.009562 & 880 & -0.001757 & 1.99 & 5.44 \\
Ur-6 & 809 & -0.004329 & 343 & -0.001514 & 2.36 & 2.86 \\
Ur-20 & 754 & -0.003912 & 446 & -0.001464 & 1.69 & 2.67 \\
Us4-3 & 1535 & -0.006991 & 224 & -0.001589 & 6.85 & 4.40 \\
Us4-10 & 1446 & -0.004261 & 505 & -0.001521 & 2.86 & 2.80 \\
Us2-6 & 330 & -0.002772 & 204 & -0.001551 & 1.62 & 1.79 \\
Us2-20 & 326 & -0.007134 & 195 & -0.001567 & 1.67 & 4.55 \\
\hline
\end{tabular}

$\overline{P_{u}}$ : axial load capacity; $\varepsilon_{u}$ : steel axial strain at axial load capacity; $P_{y s}$ : axial load at biaxial steel yielding; $\varepsilon_{y s}$ : axial strain at biaxial steel yielding.

\subsubsection{Quantification of Lateral Stresses and Concrete Confinement}

Lateral stress/pressure $\left(f_{2}\right)$ developed in the steel tube as shown in Figure 9 can be calculated by Equation $(2)[9,23]$. As concrete crushes in order for lateral stresses to initialize on the steel tube, lateral pressure is expected to be at a maximum when steel 
yields. Hoop stress, $\sigma_{h}$, can be substituted from Equation (1) to (2), where $\alpha$ is obtained from experimental results.

$$
f_{2}=\frac{2 t}{D-2 t} \sigma_{h}=\frac{2 t}{D-2 t} \alpha f_{y s}
$$
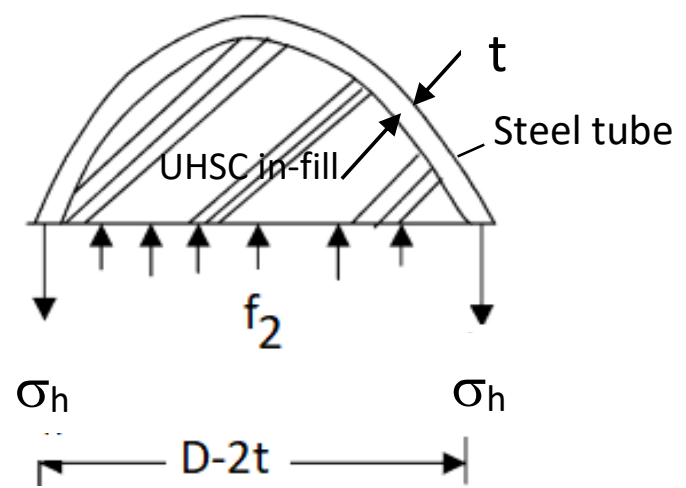

Figure 9. Lateral stress/pressure and hoop stress development in the steel tube.

Lateral pressure $\left(f_{2}\right)$ is related to the tube wall thickness $(t)$ and equivalent outer diameter $(D)$ of the cross-section (as the equation is designed for circular cross-sections, square or rectangular sections are converted to circular sections with equivalent area).

The maximum lateral pressure $\left(f_{2 \max }\right)$ in CFST columns with additional confinement due to tie or hoop reinforcement can be calculated by Equation (3).

$$
f_{2 \max }=\frac{2 t}{D-2 t} \alpha f_{y s}+\frac{2 A_{s r} f_{y r}}{D_{c} s}
$$

where $A_{s r}$ and $f_{y r}$ are area and yield strength of hoop/tie reinforcing bars and $D_{c}$ is the diameter of concrete confined by hoops, and $s$ is the hoop spacing.

Biaxial yielding of steel always occurred before the ultimate capacity of the column. Therefore, it can be assumed that CFST column ultimate capacity is associated with the maximum confined concrete strength. Total axial load $(P)$ can be separated by the portion carried by concrete $\left(P_{c}\right)$ and that carried by steel $\left(P_{s}\right)$ as in Equation (4). Axial concrete stress $\left(f_{c}\right)$ can be obtained from Equation (5) and $P_{s}$ from Equation (6). $A_{s}$ and $A_{c}$ are the steel tube cross-sectional area and concrete core area respectively.

$$
\begin{gathered}
P=P_{c}+P_{s} \\
f_{c}=\frac{P_{c}}{A_{c}}=\frac{P-P_{s}}{A_{c}} \\
P_{s}=A_{s} \sigma_{a}=A_{s} E_{t} \varepsilon_{t}
\end{gathered}
$$

where $A_{s}$ and $A_{c}$ are the steel tube cross-sectional area and concrete core area respectively, $\sigma_{a}$ is the axial stress in steel tube, $E_{t}$ and $\varepsilon_{t}$ are the elastic modulus and axial strain in steel tube, respectively.

Load carried by the steel tube $\left(P_{s}\right)$ can be calculated from the experimental axial steel tube strain $\left(\varepsilon_{t}\right)$. Variation of concrete stress $\left(f_{c}\right)$, which can be considered as experimental concrete confined strength during loading history can be calculated based on Equation (5). Typical concrete stress $\left(f_{c}\right)$ vs. axial steel tube strain $\left(\varepsilon_{t}\right)$ development during loading history for a CFST column is shown in Figure 10a,b. It can be observed that axial concrete stress decreased soon after a peak is reached in square and rectangular columns (Figure 10b) compared with circular ones (Figure 10a). Such a decrease in concrete axial stress after the peak is especially evident in columns with higher slenderness. This can be attributed to the difference in tube shape and thickness. 


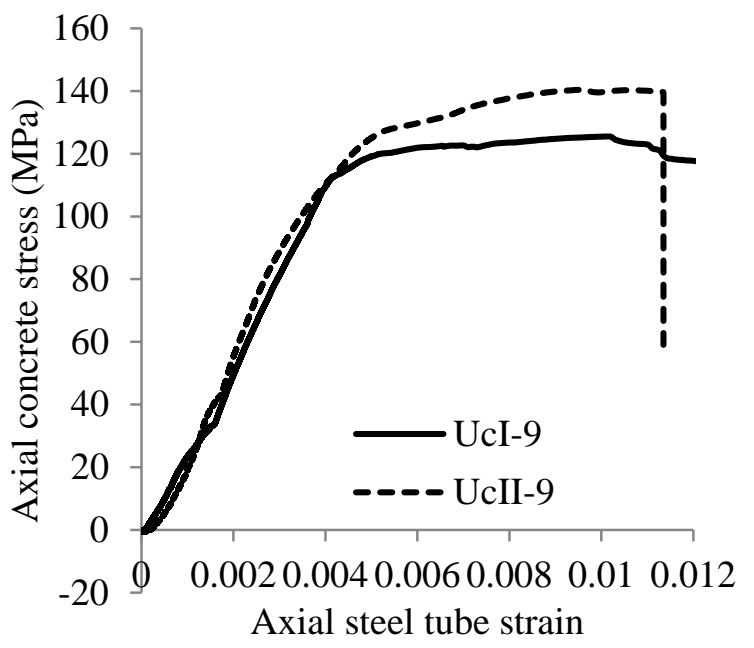

(a) Circular CFST

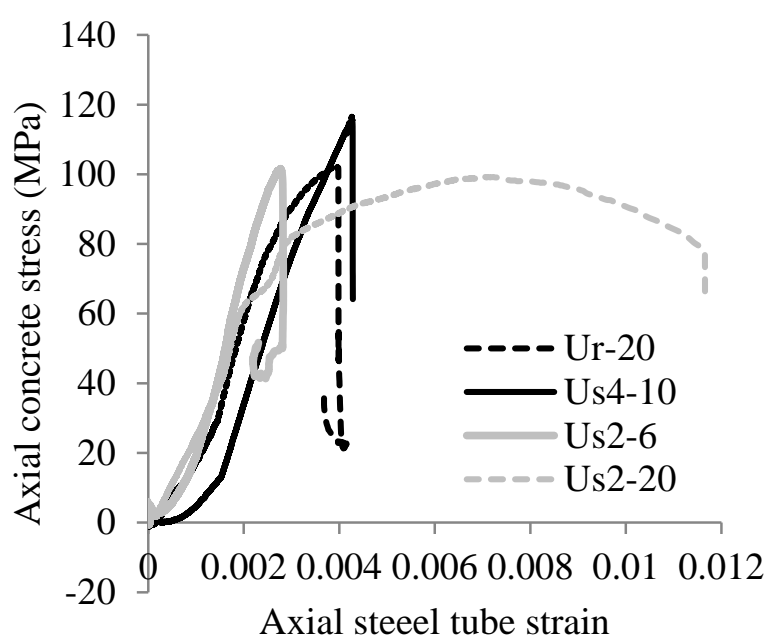

(b) Rectangular and square CFST

Figure 10. Axial concrete stress vs. steel tube strain development in CFST columns.

Total lateral stress on the steel $\left(f_{2 \max }\right.$ or $\left.f_{2}\right)$ calculated as per Equations (2) and (3) are presented in Table 4. From graphs such as shown in Figure 10, the $\mathrm{f}_{\mathrm{c}}$ value at ultimate load can be extracted as experimental confined concrete strength $\left(f^{\prime} c\right)$ and are also presented in Table 4 for columns (of each group) having a minimum and maximum slenderness ratio. Confined concrete strength is then compared with concrete control cylinder compressive strength $\left(f_{c}^{\prime}\right)$ by $f_{c c}^{\prime} / f_{c}^{\prime}$ ratios. The confined strength of UHSC-filled columns increased with the increase of steel tube thickness and also tended to decrease for UHSC-filled columns with higher slenderness. Series II columns allowed for greater confined concrete strength $\left(f_{c c}^{\prime} / f_{c}\right.$ values ranging between 1.17 and 1.27$)$ and particularly high values of $f_{2 \text { max }}$ due to contributions from bar reinforcements (Table 4). On the other hand, square and circular columns showed lower confinement effects compared to circular ones as evident from the $f_{c c}^{\prime} / f_{c}^{\prime}$ values ranging between 0.78 and 0.98 . Overall $f^{\prime}{ }_{c c} / f_{c}^{\prime}$ ratios for UHSC-filled steel tube columns ranged from 0.78 to 1.27 . This has been observed by other researchers studying high-strength CFST columns [8]. It is expected that the use of high-strength steel will improve the effect of UHSC confinement [25].

Table 4. Quantified concrete confined strength.

\begin{tabular}{cccc}
\hline Column & $f^{\prime}{ }_{c c}, \mathbf{M P a}$ & $f^{\prime}{ }_{c c} / f^{\prime}{ }_{c}$ & $f_{2}$ or $f_{2 \text { max }}, \mathbf{M P a}$ \\
\hline UcI-3 & 139 & 1.09 & 5.2 \\
UcI-9 & 125 & 0.99 & 7.0 \\
UcII-3 & 161 & 1.27 & 108.0 \\
UcII-9 & 140 & 1.11 & 97.3 \\
Ur-6 & 113 & 0.89 & 2.2 \\
Ur-20 & 102 & 0.81 & 4.1 \\
Us4-3 & 124 & 0.98 & 2.7 \\
Us4-10 & 117 & 0.92 & 4.0 \\
Us2-6 & 102 & 0.80 & 4.5 \\
Us2-20 & 99 & 0.78 & 4.3
\end{tabular}

$\overline{f_{c c}}$ : experimental confined concrete strength; $f_{c}^{\prime}$ : unconfined concrete control cylinder compressive strength; $f_{2 m a x}$ : maximum lateral pressure.

\section{Analytical Models for Confined Concrete Strength}

Richart et al. [26], Mander et al. [27], and O'Shea and Bridge's [28] models are modified for calculating confined strength of concrete in CFST columns. The total concrete confined strength $\left(f^{\prime} c c t\right)$ as presented in Equation (7) is considered as the summation of contributions derived from confining steel tube $\left(f_{c c}^{\prime}\right)$ and reinforcing hoops $\left(f_{c c h}^{\prime}\right)$ where $A_{c c}$ and $A_{c c h}$ are area confined by the steel tube and area confined by hoops respectively. The total 
concrete confined strength $\left(f_{c c t}^{\prime}\right)$ models based on Richart et al. [26], Mander et al. [27], and $\mathrm{O}^{\prime}$ Shea and Bridge [28] are presented with subscripts $\mathrm{R}, \mathrm{M}$, and $\mathrm{O}$, respectively in Equations (8)-(10).

$$
\begin{aligned}
& f^{\prime}{ }_{c c t}=f^{\prime}{ }_{c c}\left(\frac{A_{c c}}{A_{c}}\right)+f^{\prime}{ }_{c c h}\left(\frac{A_{c c h}}{A_{c}}\right) \\
& {f^{\prime}}^{\prime}{ }_{c c t(R)}=\frac{A_{c c}}{A_{c}}\left[f^{\prime}{ }_{c}+8.2 \frac{t \alpha f_{y s}}{D-2 t}\right]+8.2 \frac{A_{s r} f_{y r}}{D_{c} s} \frac{A_{c c h}}{A_{c}} \\
& f^{\prime}{ }_{c c t(M)}=\frac{A_{c c} f_{c} c_{c}}{A_{c}}\left(2.254 \sqrt{1+15.88 \frac{t \alpha f_{y s}}{f^{\prime}{ }_{c}(D-2 t)}}-4 \frac{t \alpha f_{y s}}{f_{f^{\prime}}(D-2 t)}-1.254\right) \\
& +\frac{A_{c c h} f_{c}^{\prime} c}{A_{c}}\left(2.254 \sqrt{1+15.88 \frac{A_{s r} f_{y r}}{f_{c}^{\prime} D_{c} s}}-4 \frac{A_{s r} f_{y r}}{f^{\prime}{ }_{c} D_{c} s}-0.254\right) \\
& f^{\prime}{ }_{c c t(O)}=\frac{A_{c c} f^{\prime} c}{A_{c}}\left(2.172 \sqrt{1+14.92 \frac{t \alpha f_{y s}}{f^{\prime}{ }_{c}(D-2 t)}}-4 \frac{t \alpha f_{y s}}{f^{\prime}{ }_{c}(D-2 t)}-1.228\right) \\
& +\frac{A_{c c h} f_{c}^{\prime} c}{A_{c}}\left(2.172 \sqrt{1+14.92 \frac{A_{s r} f_{y r}}{f_{c}^{\prime} D_{c} s}}-4 \frac{A_{s r} f_{y r}}{f^{\prime}{ }_{c} D_{c} s}-0.228\right)
\end{aligned}
$$

The first part in Equations (8)-(10), represents contribution due to steel tube confinement and second part represents contribution due to hoop steel confinement (can be eliminated for Series I CFST columns where hoop reinforcements were not present). According to Equations (8)-(10), increased diameter of concrete confined by hoops $\left(D_{c}\right)$ and hoop spacing (s) are expected to lower hoop confined concrete strength $\left(f_{c c h}\right)$. In order for these equations to apply for CFST columns of square/rectangular cross-sections, diameter

\begin{tabular}{|c|c|c|c|c|c|c|c|}
\hline \multirow[b]{3}{*}{ Column } & \multicolumn{4}{|c|}{ Confined Concrete Strength $\left(f^{\prime} c c t\right), \mathrm{MPa}$} & \multirow{2}{*}{\multicolumn{3}{|c|}{$\begin{array}{l}\text { Ratio of Confined Concrete } \\
\text { Strength Theoretical/Test }\end{array}$}} \\
\hline & \multirow[b]{2}{*}{ Test } & \multicolumn{3}{|c|}{ Theoretical Models } & & & \\
\hline & & $\begin{array}{c}f_{c c t(R)} \\
\text { Equation } \\
\quad(8)\end{array}$ & $\begin{array}{c}f_{c c t(M)} \\
\text { Equation } \\
\quad(9)\end{array}$ & $\begin{array}{c}f_{c c t(O)}^{\prime} \\
\text { Equation } \\
\quad(10)\end{array}$ & $\begin{array}{l}\text { Equation } \\
\quad(8)\end{array}$ & $\begin{array}{l}\text { Equation } \\
\text { (9) }\end{array}$ & $\begin{array}{l}\text { Equation } \\
\quad(10)\end{array}$ \\
\hline UcI-3 & 139 & 148 & 160 & 149 & 1.07 & 1.15 & 1.07 \\
\hline UcI-9 & 125 & 156 & 170 & 158 & 1.24 & 1.36 & 1.26 \\
\hline UcII-3 & 161 & 158 & 246 & 231 & 0.98 & 1.52 & 1.43 \\
\hline UcII-9 & 140 & 140 & 220 & 208 & 1.00 & 1.57 & 1.48 \\
\hline Ur-6 & 113 & 136 & 142 & 133 & 1.21 & 1.26 & 1.18 \\
\hline Ur-20 & 102 & 144 & 153 & 143 & 1.41 & 1.50 & 1.40 \\
\hline Us4-3 & 124 & 138 & 145 & 136 & 1.11 & 1.16 & 1.09 \\
\hline Us4-10 & 117 & 143 & 153 & 142 & 1.23 & 1.31 & 1.22 \\
\hline Us2-6 & 102 & 145 & 156 & 145 & 1.43 & 1.53 & 1.43 \\
\hline Us2-20 & 99 & 144 & 154 & 144 & 1.45 & 1.55 & 1.45 \\
\hline
\end{tabular}
(D) must be calculated for a circle of equivalent area.

\section{Performance of Confined Concrete Strength Models}

In Table 5, total confined concrete strength $\left(f^{\prime} c c t\right)$ calculated based on analytical models (Equations (8)-(10)) and those derived from experiments (Table 4) are compared.

Table 5. Validation of analytical models for confined concrete strength.

All models overpredicted confined concrete strength of square and rectangular CFST columns, as well as Series II columns infilled with UHSC. Experimental studies have shown that concrete confinement is most significant for CFST columns with a circular cross-section, due to better hoop stress development [29]. Therefore, converting square and rectangular cross-sections into equivalent circular sections overestimates the confinement effect in these columns. Theoretical/test ratios are especially high for columns infilled with UHSC with higher L/D ratios, as analytical models were not developed to account for 
global buckling failures. The Mander et al.-based model generally made slightly higher estimations compared with other models.

\section{Development of Strength Models for CFST Columns}

\subsection{Code-Based Design Procedures for CFST Columns}

Several design codes have incorporated procedures for CFST column strength calculations. Canadian, American, and European codes are studied herein and are briefly described as follows.

Compressive resistance of CFST columns $\left(C_{r c}\right)$ is given in the CAN/CSA S16-09 [21] code by Equation (11).

$$
C_{r c}=\left(\tau \varphi_{s} A_{s} f_{y}+\tau^{\prime} \alpha_{1} \varphi_{c} A_{c} f_{c}^{\prime}\right)\left(1+\lambda^{2 n}\right)^{\frac{-1}{n}}
$$

Reduction factors $\phi_{s}$ and $\phi_{c}$ are equal to unity in order to compare with experimental results. The effects of slenderness and the diameter-to-thickness ratio are incorporated into $\tau$ and $\tau^{\prime}$ strength modification factors. An equivalent elastic modulus and moment of inertia for the composite section, $E I_{e}$, is calculated in order to obtain elastic critical load in determining relative slenderness, $\lambda . \alpha_{1}=0.85-0.0015 f^{\prime}$ c , and $\mathrm{n}$ factor is taken with a value of 1.80 .

The load capacity of CFST columns $\left(P_{n}\right)$ as defined by the AISC [22] code is as follows in Equation (12).

$$
P_{n}=\left\{\begin{array}{cl}
P_{o}\left(0.658^{\frac{P_{o}}{P_{e}}}\right), & 0.44 P_{o} \leq P_{e} \\
0.877 P_{e}, & 0.44 P_{o}>P_{e}
\end{array}\right.
$$

The cross-sectional shape is considered by a factor in $P_{o}$, where $P_{o}$ is the sum of axial loads carried by the concrete core, steel tube, and bar reinforcements. The term, $P_{e}$, is the elastic critical load which incorporates an equivalent elastic modulus and moment of inertia for the composite section, and column boundary conditions, similar to the Canadian code.

Eurocode 4 [20] takes the sum of concrete, steel, and bar reinforcement cross-section contributions in Equation (13) to obtain the ultimate load capacity of CFST columns $\left(N_{p l, R d}\right)$. Reinforcement area and bar strength are denoted by $A_{s z}$ and $f_{y r}$, respectively. The effect of confinement is considered by $\eta_{a}$ and $\eta_{b}$ modification factors.

$$
N_{p l . R d}=\eta_{a} A_{s} f_{y}+\eta_{b} A_{c} f^{\prime}{ }_{c}+A_{s z} f_{y r}
$$

\subsection{Suggested Analytical Models for the Strength of CFST Columns}

Three analytical models for axial strength $\left(N_{a}\right)$ of CFST columns (denoted by subscripts $N_{a(R)}, N_{a(M)}$, and $N_{a(O)}$ based on Equation (14) are derived by substituting $f_{c c}^{\prime}$ and $f^{\prime} c c h$ values from Richart et al. [26], Mander et al. [27], and O'Shea and Bridge [28], presented in Equations (8)-(10), respectively:

$$
N_{a(R)}=N_{a(M)}=N_{a(O)}=\beta A_{s} f_{y s}+A_{c c} f_{c c}^{\prime}+A_{c c h} f_{c c h}^{\prime}+A_{r a} f_{y r}
$$

where steel tube-sectional area, tube confined area, hoop confined area, area of longitudinal reinforcements, and axial stress factor (taken from experimental results) are denoted by $A_{S}$, $A_{c c}, A_{c c h}, A_{r a}$, and $\beta$, respectively.

Equation (14) can be applied to Series I and Series II CFST columns, as terms corresponding to bar and hoop confined strength can be eliminated for columns without such reinforcements.

\subsection{Performance of Strength Prediction Models and Identification of the Most Suitable Model}

Table 6 compares experimental axial load capacities $\left(P_{\text {expt }}\right)$ of CFST columns with those predicted $\left(P_{p}\right)$ from three theoretical models (Equation (14)) and three code-based models (CSA, AISC, and Eurocode 4). All the three models were found to overpredict the 
axial load capacities UHSC-filled CFST as the ratio of experimental to predicted values $\left(P_{\text {exp }} / P_{p}\right)$ are found to be less than 1.0. This may be attributed to the overestimation of confined concrete strength especially for CFST columns with higher slenderness (L/D or L/d) ratios. Possible reasons for lower experimental concrete confined strength than theoretical might be due to high strength/stiffness of UHSC which prevented effective concrete dilation resulting in lower steel confinement.

Table 6. Comparative study of strength prediction by analytical models.

\begin{tabular}{|c|c|c|c|c|c|c|c|c|c|c|c|c|c|}
\hline \multirow{3}{*}{$\begin{array}{l}\text { Column } \\
\text { Desig. }\end{array}$} & \multicolumn{7}{|c|}{ Axial Strength (kN) } & \multirow{2}{*}{\multicolumn{6}{|c|}{$\begin{array}{l}\text { Ratio of Strength (Test/Predicted) } \\
P_{\exp } / P_{p}\end{array}$}} \\
\hline & \multirow{2}{*}{$\begin{array}{l}\text { Test } \\
P_{\text {exp }}\end{array}$} & \multicolumn{3}{|c|}{ Predicted (Equation (14)) } & \multicolumn{3}{|c|}{$\begin{array}{l}\text { Predicted by Codes } \\
\text { Equations (11)-(13) }\end{array}$} & & & & & & \\
\hline & & $N_{a(R)}$ & $N_{a(M)}$ & $N_{a(O)}$ & $\begin{array}{l}\text { CSA } \\
{[18]}\end{array}$ & $\begin{array}{l}\text { AISC-LRFD } \\
{[19]}\end{array}$ & $\begin{array}{l}\text { EC4 } \\
{[20]}\end{array}$ & $\frac{P_{e x p}}{N_{a(R)}}$ & $\frac{P_{e x p}}{N_{a(M)}}$ & \multirow{2}{*}{$\frac{\frac{P_{\text {exp }}}{N_{a(O)}}}{0.95}$} & \multirow{2}{*}{$\begin{array}{l}\text { CSA } \\
1.04\end{array}$} & \multirow{2}{*}{$\begin{array}{c}\text { AISC } \\
1.07\end{array}$} & EC4 \\
\hline UcI-3 & 1681 & 1764 & 1864 & 1768 & 1624 & 1569 & 2029 & 0.95 & 0.90 & & & & 0.83 \\
\hline UcI-4 & 1610 & 1776 & 1883 & 1785 & 1564 & 1541 & 1913 & 0.91 & 0.86 & 0.90 & 1.03 & 1.04 & 0.84 \\
\hline UcI-9 & 1573 & 1805 & 1929 & 1823 & 1382 & 1417 & 1858 & 0.87 & 0.82 & 0.86 & 1.14 & 1.11 & 0.85 \\
\hline UcII-3 & 1853 & 1950 & 2705 & 2576 & 1624 & 1692 & 2155 & 0.95 & 0.69 & 0.72 & 1.14 & 1.10 & 0.86 \\
\hline UcII-4 & 1849 & 1916 & 2655 & 2533 & 1564 & 1660 & 2039 & 0.97 & 0.70 & 0.73 & 1.18 & 1.11 & 0.91 \\
\hline UcII-9 & 1751 & 1840 & 2530 & 2427 & 1382 & 1516 & 1984 & 0.95 & 0.69 & 0.72 & 1.27 & 1.16 & 0.88 \\
\hline Ur-6 & 809 & 874 & 899 & 860 & 825 & 743 & 991 & 0.93 & 0.90 & 0.94 & 0.98 & 1.09 & 0.82 \\
\hline Ur-12 & 987 & 885 & 917 & 876 & 739 & 690 & 956 & 1.12 & 1.08 & 1.13 & 1.34 & 1.43 & 1.03 \\
\hline Ur-20 & 754 & 899 & 941 & 896 & 577 & 578 & 1115 & 0.84 & 0.80 & 0.84 & 1.31 & 1.30 & 0.68 \\
\hline Us4-3 & 1535 & 1633 & 1695 & 1610 & 1434 & 1370 & 1925 & 0.94 & 0.91 & 0.95 & 1.07 & 1.12 & 0.80 \\
\hline Us4-6 & 1397 & 1646 & 1720 & 1630 & 1366 & 1334 & 1809 & 0.85 & 0.81 & 0.86 & 1.02 & 1.05 & 0.77 \\
\hline Us4-10 & 1446 & 1665 & 1751 & 1657 & 1252 & 1251 & 1791 & 0.87 & 0.83 & 0.87 & 1.15 & 1.16 & 0.81 \\
\hline Us2-6 & 330 & 424 & 448 & 423 & 347 & 337 & 456 & 0.78 & 0.74 & 0.78 & 0.95 & 0.98 & 0.72 \\
\hline Us2-9 & 376 & 423 & 447 & 423 & 326 & 322 & 452 & 0.89 & 0.84 & 0.89 & 1.15 & 1.17 & 0.83 \\
\hline Us2-12 & 348 & 423 & 446 & 422 & 300 & 303 & 458 & 0.82 & 0.78 & 0.82 & 1.16 & 1.15 & 0.76 \\
\hline Us2-16 & 366 & 423 & 446 & 422 & 249 & 218 & 282 & 0.87 & 0.82 & 0.87 & 1.47 & 1.68 & 1.30 \\
\hline Us2-20 & 326 & 422 & 445 & 421 & 231 & 209 & 283 & 0.77 & 0.73 & 0.77 & 1.41 & 1.56 & 1.15 \\
\hline \multicolumn{6}{|c|}{ R: Richart et al.; M: Mander et al.; O: O'Shea and Bridge } & \multicolumn{2}{|c|}{ Mean ratio } & 0.90 & 0.82 & 0.86 & 1.17 & 1.19 & 0.87 \\
\hline
\end{tabular}

The Mander et al. (M)-based model [27] typically resulted in higher overestimations $\left(P_{\text {exp }} / P_{p}\right.$ ranged between 0.73 and 1.08 with a mean value of 0.82$)$, followed by the $\mathrm{O}^{\prime}$ Shea and Bridge $(\mathrm{O})$-based model [28] $\left(P_{\text {exp }} / P_{p}\right.$ ranged between 0.77 and 1.13 with a mean value of 0.86), and the Richart et al. (R)-based model [26] $\left(P_{\text {exp }} / P_{p}\right.$ ranged between 0.77 and 1.12 with a mean value of 0.90 ). The Richart et al. (R)-based model performed especially well for columns with bar reinforcements. Although performance is quite similar among the three suggested analytical models, the Richart et al. (R)-based model predictions (with mean $P_{\exp } / P_{p}$ value of 0.90 ) are closer to the experimental results and can be used for design purposes by introducing a reduction factor of 0.90 and 0.75 for circular and square/rectangular UHSC based CFST columns, respectively.

Eurocode [20] followed a similar trend in overpredicting the axial load capacity of UHSC-filled CFST columns (with a mean $P_{\text {exp }} / P_{p}$ value of 0.87 ) compared to the three suggested analytical models in Table 6. Alternatively, CSA [21] and AISC [22] models performed similarly well in underestimating axial capacity of UHSC-filled tube columns, although they become quite conservative as slenderness increased, particularly for Series I and Series II circular columns (although CSA provisions did not account for bar reinforcements). The AISC [22] model was found to be slightly more applicable to square 
CFST columns compared with that of the CSA design code, as the AISC model especially accounted for the effect of cross-sectional shape. CSA (with a mean $P_{\exp } / P_{p}$ value of 1.17) and AISC (with a mean $P_{\exp } / P_{p}$ value of 1.19) models performed well and can be used in predicting axial load capacity of UHSC-filled CFST columns within the range of geometric configurations used in this study.

\section{Conclusions}

This paper analyzed concrete-filled steel tube (CFST) columns with self-consolidating fiber-reinforced ultrahigh-strength concrete (UHSC) core material. Columns were tested under concentric axial compression loading to failure. Axial load-displacement behavior, stress-strain response, concrete confined strength, and axial load capacity/strength of CFST columns were studied and compared with analytical models and code-based design equations. The effects of cross-sectional shape and area, length-to-diameter (L/D) or lengthto-depth $(\mathrm{L} / \mathrm{d})$ ratios, tube wall thickness $(\mathrm{t})$, and longitudinal steel reinforcing bars with hoops were investigated for their effects on behavior of UHSC-filled tube columns. The following conclusions are drawn from this study.

- UHSC-filled CFST columns failed to exhibit different types of failure based on slenderness (L/D or L/d ratios). Failure modes included global buckling for slenderness ranging between 16 and 20, shear yielding associated with successive formation of local buckling for slenderness varying from 4 to 12 , and radial expansion with tube tearing for slenderness of 3 .

- Axial load-displacement responses of circular CFST columns generally showed multiple peaks and drops showing increase in load after each drop producing large post-peak deformation (ductility) before failure but the first peak always governed the load capacity. Square and rectangular columns displayed similar load-displacement responses exhibiting decrease in load after the first peak and lower ductility.

- Axial load capacity/strength generally decreased with the increase of slenderness and increased with the presence of longitudinal and hoop reinforcement. Circular columns showed higher axial load strength and ductility compared to their rectangular/square counterparts. The combined effect of $\mathrm{D} / \mathrm{t}, \mathrm{L} / \mathrm{D}$ or $\mathrm{L} / \mathrm{d}$, steel tube geometry and failure modes governed the axial strength of CFST columns.

- Experimental UHSC confined strength increased with the increase of tube thickness, decreased for columns of higher slenderness and increased (by 11 to $27 \%$ ) with the presence of longitudinal and hoop reinforcements. Existing analytical models overestimated the confined concrete strength resulting from tube and hoop confinement in CFST columns compared to those of experiments. This is attributed to overestimating the ability of UHSC to soften and dilate with progressive loading.

- Predicted axial strength from the three suggested analytical models were often greater than those obtained from experiments. This overestimation is attributed to the overprediction of confined UHSC strength and reduction factors are suggested for incorporation in analytical models for strength prediction.

- Eurocode 4 overpredicted the strength of CFST columns. Canadian CAN/CSA S16-09 and American AISC code provisions performed well, especially in estimating the strength of circular columns with or without bar/hoop reinforcements. The AISC code was especially good for square and rectangular UHSC-filled tube columns as it took into account cross-sectional shape.

Author Contributions: Conceptualization, K.M.A.H.; Methodology, K.M.A.H. and K.C.; Formal Analysis, K.M.A.H., K.C. and M.S.A.; Investigation, K.M.A.H. and K.C.; Resources, K.M.A.H.; Data Curation, K.M.A.H. and M.S.A.; Writing-Original Draft Preparation, K.M.A.H., K.C. and M.S.A.; Writing-Review \& Editing, K.M.A.H. and M.S.A.; Supervision, K.M.A.H.; Project Administration, K.M.A.H.; Funding Acquisition, K.M.A.H. All authors have read and agreed to the published version of the manuscript. 
Funding: This research was funded by [Natural Science and Engineering Research Council (NSERC), Canada] grant number [RGPIN/5757-2014]. And the APC was funded by MDPI [free]: Author Voucher discount code -ac659ffd85394b67.

Institutional Review Board Statement: Not applicable.

Informed Consent Statement: Not applicable.

Data Availability Statement: The data presented in this study are available on request from the corresponding author.

Acknowledgments: The authors gratefully acknowledge the financial support provided by Natural Science and Engineering Research Council (NSERC), Canada.

Conflicts of Interest: The authors declare no conflict of interest.

\section{References}

1. Dai, X.H.; Lam, D.; Jamaluddin, N.; Ye, J. Numerical analysis of slender elliptical concrete filled columns under axial compression. Thin-Walled Struct. 2014, 77, 26-35. [CrossRef]

2. Inai, E.; Mukai, A.; Kai, M.; Tokinoya, H.; Fukumoto, T.; Mori, K. Behavior of concrete-filled steel tube beam columns. J. Struct. Eng. ASCE 2004, 130, 189-202. [CrossRef]

3. Lachemi, M.; Hossain, K.M.A.; Lambros, V. Axial load behavior of self-consolidating concrete filled steel tube columns in construction and service stages. ACI Struct. J. 2006, 103, 38-47.

4. Nie, J.-G.; Wang, Y.-H.; Fan, J.-S. Experimental study on seismic behavior of concrete filled steel tube columns under pure torsion and compression-torsion cyclic load. J. Constr. Steel Res. 2012, 79, 115-126. [CrossRef]

5. Shakir-Khalil, H.; Zeghiche, J. Experimental behavior of concrete filled rolled rectangular hollow section columns. J. Struct. Eng. ASCE 1989, 67, 346-353.

6. Gupta, P.; Sarda, S.; Kumar, M. Experimental and computational study of concrete filled steel tubular columns under axial loads. J. Constr. Steel Res. 2007, 63, 182-193. [CrossRef]

7. Vrcelj, Z.; Uy, B. Strength of slender concrete-filled steel box columns incorporating local buckling. J. Constr. Steel Res. 2002, 58, 275-300. [CrossRef]

8. Yu, Q.; Tao, Z.; Wu, Y.-X. Experimental behaviour of high performance concrete-filled steel tubular columns. Thin Walled Struct. 2008, 46, 362-370. [CrossRef]

9. Lachemi, M.; Hossain, K.; Lambros, V. Self-consolidating concrete filled steel tube columns—Design equations for confinement and axial strength. Struct. Eng. Mech. 2006, 22, 541-562. [CrossRef]

10. Hossain, K.M.A.; Mak, C.; Ametrano, D. GFRP reinforced UHPC composites for sustainable bridge construction. Can. Civ. Eng. 2012, 29, 12-15.

11. Graybeal, B.A. Compressive behavior of ultra-high performance fibre-reinforced concrete. ACI Mat. J. 2007, 104, 146-152.

12. Tafraoui, A.; Escadeillas, G.; Lebaili, S.; Vidal, T. Metakaolin in the formulation of UHPC. Constr. Build. Mater. 2009, 23, 669-674. [CrossRef]

13. Song, T.-Y.; Xiang, K. Performance of axially-loaded concrete-filled steel tubular circular columns using ultra-high strength concrete. Structures 2020, 24, 163-176. [CrossRef]

14. Xiong, M.-X.; Liew, J.Y.R. Buckling behavior of circular steel tubes infilled with C170/185 ultra-high-strength concrete under fire. Eng. Struct. 2020, 212, 10523. [CrossRef]

15. Liew, J.R.; Xiong, D. Ultra-High Strength Concrete Filled Composite Columns for Multi-Storey Building Construction. Adv. Struct. Eng. 2012, 15, 1487-1503. [CrossRef]

16. Chen, S.; Zhang, R.; Jia, L.-J.; Wang, J.-Y.; Gu, P.; Xiong, M.-X.; Xiong, D.-X.; Liew, J.Y.R. Behaviour of steel tubular members infilled with ultra-high strength concrete. J. Constr. Steel Res. 2017, 138, 168-183.

17. Chen, S.; Zhang, R.; Jia, L.-J.; Wang, J.-Y.; Gu, P. Structural behavior of UHPC filled steel tube columns under axial loading. Thin-Walled Struct. 2018, 130, 550-563. [CrossRef]

18. Xiong, M.-X.; Xiong, D.-X.; Liew, J.R. Axial performance of short concrete filled steel tubes with high- and ultra-high-strength materials. Eng. Struct. 2017, 136, 494-510. [CrossRef]

19. Liu, S.; Ding, X.; Li, X.; Liu, Y.; Zhao, S. Behavior of Rectangular-Sectional Steel Tubular Columns Filled with High-Strength Steel Fiber Reinforced Concrete Under Axial Compression. Materials 2019, 12, 2716. [CrossRef]

20. Eurocode 4. Design of Composite Steel and Concrete Structures, Part 1.1: General Rules and Rules for Buildings; British Standards Institution: London, UK, 2004.

21. CAN/CSA S16-09. Limit States Design of Steel Structures, Rexdale; Canadian Standards Association: Toronto, ON, Canada, 2009.

22. American Institute of Steel Construction (AISC). Manual of Steel Construction, Load and Resistance Factor Design, 3rd ed.; AISC: Chicago, IL, USA, 2005.

23. Hossain, K.M.A. Behaviour of thin walled composite columns under axial loading. Compos. Part B Eng. 2003, 34, 715-725. [CrossRef] 
24. Sakino, K.; Nakahara, H.; Morino, S.; Nishiyama, I. Behavior of Centrally Loaded Concrete-Filled Steel-Tube Short Columns. J. Struct. Eng. 2004, 130, 180-188. [CrossRef]

25. Fujimoto, T.; Mukai, A.; Nishiyama, I.; Sakino, K. Behavior of Eccentrically Loaded Concrete-Filled Steel Tubular Columns. J. Struct. Eng. 2004, 130, 203-212. [CrossRef]

26. Richart, F.E.; Brandtzaeg, A.; Brown, R.L. A Study of the Failure of Concrete under Combined Compressive Stresses; Bulleting \#185; University of Illinois, Engineering Experimental Station: Urbana, IL, USA, 1928.

27. Mander, J.B.; Priestley, M.J.N.; Park, R. Theoretical Stress-Strain Model for Confined Concrete. J. Struct. Eng. 1988, 114, 1804-1826. [CrossRef]

28. O'Shea, M.D.; Bridge, R.Q. Design of circular thin-walled concrete filled steel tubes. J. Struct. Eng. ASCE 2000, 126, 1295-1303. [CrossRef]

29. Schneider, S.P. Axially loaded concrete-filled steel tubes. J. Struct. Eng. ASCE 1998, 124, 1125-1138. [CrossRef] 